\title{
Paideusis
}

\section{Rearticulating Youth Subjectivity Through Gay-Straight Alliances (GSAs)}

\section{Lindsay Herriot}

Volume 22, Number 1, 2014

Sexual and Gender Diversity in Schools

URI: https://id.erudit.org/iderudit/1071464ar

DOI: https://doi.org/10.7202/1071464ar

See table of contents

Publisher(s)

Canadian Philosophy of Education Society

ISSN

0838-4517 (print)

1916-0348 (digital)

Explore this journal

Cite this article

Herriot, L. (2014). Rearticulating Youth Subjectivity Through Gay-Straight Alliances (GSAs). Paideusis, 22(1), 38-47. https://doi.org/10.7202/1071464ar
Article abstract

Populated by lesbian, gay, bisexual, trans*, queer (LGBTQ) and allied youth school-based gay straight alliances (GSAs) offer a unique opportunity to re-imagine or redefine youth subjectivity, especially with regards to the intersections of sexual orientation, gender identity, and civic rights. Tracing the evolution of youth subjectivity from the emergence of Canadian schooling in the 1860s, I turn to Ontario's Bill 13 as a recent example of how GSAs are subverting, or resisting these norms, and in so doing, operate as a kind of counter-public. Drawing from Jenks' (2005) archetypes of the Dionysian and Apollonian child, I assert that GSAs can embody a third type of child subjectivity, the Athenian child (Smith, 2011; 2014) and, in so doing, provide theoretical space to reconstitute subjectivity for all youth.
This document is protected by copyright law. Use of the services of Erudit (including reproduction) is subject to its terms and conditions, which can be viewed online.

https://apropos.erudit.org/en/users/policy-on-use/ 
Paideusis, Volume 22 (2014), No. 1, pp. 38-47

\title{
Rearticulating Youth Subjectivity Through Gay-Straight Alliances (GSAs)
}

\author{
LINDSAY HERRIOT \\ University of Alberta
}

\begin{abstract}
Populated by lesbian, gay, bisexual, trans*, queer (LGBTQ) and allied youth, school-based gay straight alliances (GSAs) offer a unique opportunity to re-imagine or redefine youth subjectivity, especially with regards to the intersections of sexual orientation, gender identity, and civic rights. Tracing the evolution of youth subjectivity from the emergence of Canadian schooling in the 1860s, I turn to Ontario's Bill 13 as a recent example of how GSAs are subverting, or resisting these norms, and in so doing, operate as a kind of counterpublic. Drawing from Jenks' (2005) archetypes of the Dionysian and Apollonian child, I assert that GS As can embody a third type of child subjectivity, the Athenian child (Smith, 2011; 2014) and, in so doing, provide theoretical space to reconstitute subjectivity for all youth.
\end{abstract}

\section{Introduction}

School-based Gay-Straight Alliances (GSAs) are primarily North American extra-curricular clubs that foster support for lesbian, gay, bisexual, trans*1, and queer (LGBTQ) middle and secondary students and their allies. Generally founded and led by youth, they sometimes take on activist or educational roles, such as lobbying for LGBTQ-inclusive curricular materials. Although there is a growing body of work on many aspects of GSAs (see Fetner \& Kush, 2008; Fetner et al., 2012; Gray, 2009; Pascoe, 2007; Russell, et al., 2009; Short, 2013), they have not yet been examined for ways in which they articulate, or redefine, youth subjectivity. This paper asserts that, simply by existing, GSAs contribute to our theorizing about who youth are and can be, particularly within schools.

Childhood innocence is a powerful force in regulating and subjugating children (Faulkner, 2011; Robinson, 2013). I contend that adults are often morally opposed to the emergence of GSAs, because they disrupt two of the pillars of regulated childhood innocence-namely, (hetero)asexuality, and passive semicitizenship. Because schools are built around particular ideals about who the child is and should be, promoting and protecting these two defining features of childhood are among the central aims of schooling. With respect to sexuality, GSAs disrupt the dominant notion that youth's sexual subjectivity is naturally and universally asexual in practice (i.e., devoid of romantic and/or sexual expression) and heterosexual in orientation (i.e., straight until adulthood) (Bruhm \& Hurley, 2004; Robinson, 2013; Stockton, 2009). Second, GSAs reconstitute the youth-citizen as less of a dependent, or illegitimate semi-citizen, and more as an active

\footnotetext{
1 "Trans*: an umbrella term that can be used to describe people whose gender identity and/or gender expression differs from what they were assigned at birth" (Vancouver School Board, 2014, p. 13).

(C) Copyright 2014. The author, Lindsay Herriot, assigns to Paideusis the right of first publication and educational and non-profit institutions a non-exclusive license to use this document for personal use and in courses of instruction provided that the article is used in full and this copyright statement is reproduced. Any other usage is probibited without the express permission of the author.
} 
participant in policy and decision-making, demonstrating a new branch in the emerging field of student voice (see Mayo, 2013; Russell et al., 2009).

In this paper, I identify how Canadian public schools were designed, among other aims, to promote these two fundamentals of youth subjectivity (hetero-asexuality, and compliant semi-citizenship). Populated as they are by self-identifying collectives of LGBTQ and allied students, GSAs naturally threaten the universality of these two aims. Using Ontario's Bill 13: The Accepting Schools Act (2012) as a recent example, I illustrate how GSAs embody Fraser's (1992) conception of counter-publics and have induced moral regulation by altering these ideals. I conclude by suggesting that GSAs reconstitute subjectivity for all youth in schools, not just LGBTQ identifying students, or GSA members.

\section{Historical (and Contemporary) Aims of Canadian Schools: Producing the "Good" Gendered Citizen}

Public education in Canada was designed for specific purposes with several defined conceptions of childhood in mind. That is, the architects of compulsory schooling had particular notions of who the child was when they designed the school system to educate him. ${ }^{2}$ The legacy of these ideals of childhood continues to inform how educationalists understand children and, therefore, how schools are organized. Compulsory public schooling emerged in mid-19th century Canada as a tool of moral regulation in a new nation (Curtis, 1994). This emergence took place amongst two competing conceptions of children, which continue to inform dominant notions of children today. Jenks (2005) relies on Greek mythology to explicate these two broad archetypes. First is the Dionysian child, who is an evil, wild, sinful, and sensual child. Schools and educational programming designed with the Dionysian child in mind are generally prescriptive and corrective, and heavily supervise, or otherwise discipline, children's thoughts and behaviours. Embodied discipline of the Dionysian child in Canadian history demonstrates gendered differences where boys were strapped or assaulted, while girls were physically isolated (Gleason, 2001). Conversely, the Apollonian child is innocent, good, natural, and angelic. The education of the Apollonian child is epitomized in Rousseau's Emile, which emphasizes learning through the senses and interactions with the world.

Depending on the issue, and often the particular children in question (and especially their racial, gendered, and class signifiers), adult conceptions of childhood can be essentialized by these archetypes. Nineteenth-century ideals of children, like those of today, are infused with characteristics of both the Dionysian and Apollonian child, although features of the Dionysian child are more prominent. Conceptions of who the child was and is continue to inform decisions about how they should be educated as gendered and sexual citizens, and therefore have particular relevance to GSAs. What follows here is an account of how youth subjectivities relating to gender and citizenship were taken up at the emergence of public education in Canada, and how the residue of these ideals remain in schooling today.

\section{Gender}

Touting biological determinism, an Ontario school inspector in 1860 remarked that " $[\mathrm{t}]$ here was considerable diversity between the mind of a girl and that of a boy" (Axelrod, 1997, p. 35). Historically within these contexts and discourses, youths are positioned as being only one of two sexes or genders (that is, boy or girl), and universal heterosexuality is seen as innate and foundational to each binary gender identity. These dimensions are espoused through a set of historical and institutionalized processes within formal educationthat is, schools normalized and solidified the spatial segregation of two distinct sexes in what is known as the "gender-role curriculum" (Gleason, 2001). For example, consider the establishment of single-sex schools, gender-segregated washrooms, and gender-segregated curricula, especially in industrial arts and domestic sciences. These policies served to maintain and reproduce broader social structures (for example, heterosexual

${ }^{2}$ I deliberately use the masculine pronoun here because adult men designed mass schooling to benefit primarily male children. 
patriarchy) through the systematic stratification of gender identities and the institutionalization of compulsory heterosexuality. Binary gender segregation further extended to the playground, with girls typically being pushed to the literal sidelines, with less physical space to play, exercise, and socialize during school breaks (Adams, 2014; Gleason, 2001, see also Gagen, 2000).

It seems paradoxical. While gender identity and sexual orientation were understood as naturally and universally cisgender ${ }^{3}$ and heterosexual, schools nonetheless invested considerable effort in teaching and enforcing gender conformity. Why would a student need to be taught something that is both natural and universal? Rules are typically established because someone is behaving contrary to the norm. We do not, for instance, create and enforce rules about breathing, which is a naturally occurring, universal phenomenon. The investment of time and resources indicates that rather than being a stable, fixed identity, cisgendered heterosexuality was seen as somewhat fragile, or at least in need of protection from corrupting influences. And while deviance was often seen as infiltrating children and schools from the outside (say, from a lurking paedophile, or "homosexual", who are often conflated as being one and the same), recent scholarship on the history of children's sexuality suggests that children have been subverting gender norms and compulsory (hetero)asexuality for generations (Egan \& Hawkes, 2010; Robinson, 2013).

Conceptions of the child vary depending on the location of the threat. When the concern is "radical homosexuals" promoting the "gay agenda" to schoolchildren, children are understood as Apollonian; that is, children are understood as being in possession of a (good), though fragile, heterosexuality that is in need of nurturing protection. When, however, the threat is a child herself, such as in the case of a transgendered girl using the girls' bathroom, the child in question is conceptualized as Dionysian, while the rest of the children are Apollonian. This is to say, she is understood as a hypersexual, deviant, and possibly contagious threat, who must be either corrected or quarantined.

\section{Citizenship Education}

Although citizenship education has taken a backseat to literacy, mathematics, and science in recent years, it was nonetheless the backbone of early Canadian curricula (DiMascio, 2010). Emerging as it did after the rebellions of the 1830 s, one of the aims of mass education was to produce and reproduce loyal, obedient patriots who would not disrupt the social order (Axelrod, 1997). This was increasingly important at a time when the enfranchisement of some white male property-owners caused white male elites to panic at the possibility of an illiterate, or civically uneducated, voter, and public schooling was conceived as a remedy for children's natural civic and moral deficiencies. Proponents of schooling believed that through "indoctrination," children would learn the subordination necessary to become loyal, obedient citizens (DiMascio, 2010).

Within liberal democracies, citizenship education is generally seen as a primary vehicle in producing "governable subjects" (Rose, 1999). This typically means inculcating values conducive to a compliant citizen, who will participate in established structures, such as voting or volunteering, without fundamentally altering the institutions themselves. Students' active citizenship within established structures at school is generally restricted to sitting on a student council, a body which has little or no real power, and whose members are sometimes handpicked by the teaching staff (Peck, Sears, \& Herriot, 2012). Otherwise, students and their views on educational policy tend to be tokenized, relegated to the margins, or outright ignored.

The student-citizen is at once the Dionysian and Apollonian child, as politics and children are understood as needing protection from one another (Cohen, 2009). Political life is thought to be better off away from children's corrupting influences, as they are thought to be incapable, immature, or just too silly for meaningful participation, and might even wreck political institutions if they try (Rudduck, 2007). Simultaneously, the rough and tumble realities of politics are deemed too harsh, too serious, for the naturally sweet, innocent, and apolitical child. The twin discourses of the Dionysian and Apollonian child can often be

\footnotetext{
${ }^{3}$ Schilt and Westbrook (2009) define cisgender as a label for "individuals who have a match between the gender they were assigned at birth, their bodies, and their personal identity" (p. 461). It is intended as a complement to transgender, and replaces non-transgender.
} 
seen in media coverage about potentially lowering the minimum voting age (see Urback, 2010). Thus, children's citizenship continues to be a highly regulated affair.

Discourses of childhood innocence further contribute to the "good' normative adult citizen-subjectthat is, white, middle-class, heterosexual adult citizens upholding of Christian family morals and values" (Robinson, 2013, p. 35). For instance, children are routinely excluded from knowledge production and debates around children's sexual citizenship, because their presumed innocence, or ignorance of these topics, is regulated, or protected (Egan, 2013; Faulkner, 2011).

\section{Legacy of These Ideals Today}

One method of discerning how $19^{\text {th }}$ and $20^{\text {th }}$ century ideals about children's sexual, gendered, and citizen subjectivity are of continuing relevance in Canadian schools is by noting how transgressions of these norms are handled. With regards to gender nonconformity, there are multiple reports of trans* youth being suspended, or otherwise disciplined for using the school bathroom that matched the gender they identify as (CTV, 2013; Gulli, 2014). This is an important example of embodied moral regulation. ${ }^{4}$ Youth-gendered subjectivity is understood as exclusively cisgendered, an assumption that is reflected in "boys" and "girls" bathroom policies in schools. Those with differing gendered subjectivities such as trans* youth are punished. Another example of the disciplining of gender nonconformity is the case of Marc Hall, who was barred in 2002 from bringing his boyfriend to his Ontario school's prom. ${ }^{5}$ The prom is, among other things, the school's ritualized celebration of compulsory heterosexuality, which was threatened by Hall's deviance. These cases, and many others like them, distil the extent to which heterosexual patriarchy is institutionalized within and by schools to promote and privilege youth's "natural" and "universal" heterosexuality and gender conformity.

Regarding civic action, a recent example from Atlantic Canada indicates how obedience is prioritized over action. Administrators at Leo Hayes High School in Fredericton, New Brunswick, prohibited students from holding anti-bullying rallies in the schools' cafeteria. The protests were designed to express student frustration with the administration's alleged inaction after a student left the school due to bullying. When the students then held demonstrations off school property during their lunch hour, they were given detentions, and threatened with having graduation privileges revoked if they continued (CTV, 2012). As students are supposed to be learning compliant citizenship in schools, their protest against the administration, both on and off campus, was seen to merit punishment. In an about-face indicating discomfort with public knowledge of compliant, rather than participatory citizenship, the punishments were revoked after the story ran in the press (CBC, 2012).

\section{GSAs: A Different Type of Gendered Student-Citizen}

First emerging in Canada in 2000, ${ }^{6}$ GSAs were originally conceived as small "safe havens" to help LGBTQ youth and their allies survive high school. Safety continues to be a concern for GSAs. Taylor's (2011) First

\footnotetext{
4"'S] ince children [have] few sources of cultural capital besides their physical selves, the body [is] an important signifier of identity and act[s] as a commodity both of belonging and ostracization" (Gleason, 2001, p. 202).

${ }^{5}$ Marc Hall took his Catholic school board to court and, hours before the prom was scheduled to begin, was informed of the ruling that he could bring the partner of his choice to the school function (Walton, 2004).

${ }^{6}$ To date, there are 283 GSAs registered on mygsa.ca, spread across all ten provinces and the Yukon Territory (mygsa.ca, 2013). This number does not take into account GSAs which have chosen not to register with mygsa.ca, or who perhaps don't know about this service provided by Equality for Gays and Lesbians Everywhere (EGALE). As well, there could also be defunct clubs that are still registered. GSAs are often fleeting and unstable, disintegrating when leaders graduate or liaison teachers leave their school (Fetner \& Kush, 2008). Despite these limitations, the mygsa.ca count is still the best available measure for tallying the number and locations of Canadian GSAs.
} 
National Climate Report on Homophobia, Biphobia, and Transphobia documents a deplorable baseline of physical, sexual, and verbal harassment and assault endured by LGBTQ youth in schools. Surveying youth in all provinces except Quebec, and all three territories $(n=3607)$, the report revealed that $70 \%$ of participants heard the disparaging "that's so gay" comment every day at school, and that nearly two-thirds of LGBTQ students, and students with an LGBTQ parent, reported feeling unsafe at school. Between one-third and onehalf of LGBTQ participants reported sexual harassment at school, while $20 \%$ of LGBTQ, and 10\% of nonLGBTQ students were physically assaulted because of their perceived gender identity or sexual orientation.

The findings from the First National Climate Report provide an important context for studying or otherwise commenting on GSAs. Whatever else GSAs may choose to do, the bravery of self-identifying as either LGBTQ or allied against this backdrop of threat, and then holding public meetings-even if it is just to eat lunch with someone who is implicitly accepting of LGBTQ people and ideas-is a radical subversion of the status quo. Moving from being targeted individuals to a self-identified collective was a change so substantial that it occupied the Ontario provincial legislative agenda for months while it considered Bill 13.

In spite of the threats to students documented in the First National Climate Report, many GSAs have broadened their mandates to include educational or activist goals. Canadian GSAs report activities such as writing and implementing a sexual harassment policy, changing board-level forms to be inclusive of samegender parents, developing education packages for their school boards, writing a newspaper article on LGBTQ issues, holding a school-wide Pride Week, participating in their community Pride parade, and delivering anti-homophobia/anti-transphobia workshops to staff and students (Fetner et al., 2012; Short, 2013). City-wide GSA conferences have been reported in Vancouver, provincial conferences in Alberta and Nova Scotia, and in the summer of 2013, the lobby group Equality for Gays and Lesbians Everywhere (EGALE) hosted the first national GSA conference in Toronto and has announced that the second will take place in Winnipeg in 2015. As of this writing, a high-school GSA in North Battleford, Saskatchewan, and the university-level GSA in Corner Brook, Newfoundland, partnered with municipal authorities to publicly raise the rainbow Pride flag in solidarity with the LGBTQ athletes at the Olympics in Sochi, Russia (Cairns, 2014; Hurley, 2014).

GSA's citizen engagement can be multi-directional and intergenerational-that is, GSA members, along with their teacher advisers, are engaging with their peers, as well as with adults, to affect meaningful change. Such engagement is not innate; rather it is taught, practiced, and learned. Networking, organizing meetings, publicizing events, speaking in public, writing policy, creating workshops, building coalitionsthese are all learned skills. While the GSA teacher adviser is frequently the lynchpin for much of this mentorship, youth members also teach and learn these activist and organizing skills from each other.

GSAs as hubs of citizen engagement mark an age-based departure from traditional queer organizing, as movements for gay liberation have a long history of being led and participated in by adults. One only has to think of the responses typically given to children who self-identify as LGBTQ (e.g., "How can you know that yet?") to know that the conception of a queer child in the present tense continues to be anathematic. With its membership assumed to be adults-only, the gay bar or dance club, which by definition is not open to minors, has long been a site of gay consciousness-raising and organizing (Fields, 2004). Having the leadership of LGBTQ social activism shift from being adult-centric to including some youth leaders, and many more as participants, and physically moving from private, adult-only establishments into public, state-funded schools indicates a substantial change in the people and processes of gay liberation. "The emergence of GSAs in high schools as legitimate, official student groups recognized by school authorities marks a moment in which young people are stepping forward to claim support for lesbian and gay rights on their own terms" (Fetner \& Kush, 2008, p. 117). Throughout all of these endeavours, GSA members are often openly and unashamedly LGBTQ (or LGBTQ-allied) and actively engaged in creating change. As this is such a marked departure from the expected, promoted, and privileged youth subjectivity in schools, it is perhaps unsurprising that GSAs have provoked intense moral regulation with a smattering of panic.

Despite these differences, GSAs are also illustrative of several important continuities-namely, around sex education and embodied resistance. In her review of Canadian autobiographical educational histories, Gleason (2001) found that sex education, when it was explicitly addressed, tended to be "... brief, presumably self-explanatory, and heterocentric" (p. 210). Sex education has never been forthcoming either at home or at school, and youth have been in/accurately educating their peers on sex and sexuality for generations. 
Autobiographies on the topic demonstrate that children have been actively subverting the embodied regulations of gender within schooling for generations (see Sutherland, Barman, \& Hale, 1992). GSAs have simply moved this peer-based sex education from whispered conversations in washrooms or back alleys to classrooms that are supervised by adults. In so doing, GSAs have formalized this ongoing subversion, transforming what were once individual acts of resistance to youth collective consciousness raising, which is supported by adult allies, and aimed at creating lasting systemic and institutional change. Acknowledging the continuity of GSAs provides necessary historical context in discerning the ways in which they are indeed indicative of substantive changes in how gender, sexuality, and citizenship are taken up in schools.

\section{Bill 13: The Accepting Schools Act}

Ontario's Bill 13: The Accepting Schools Act (hereafter referred to as 'Bill 13') was initiated in response to significant moral concerns, and in turn provoked others, including those pertaining to youths' sexuality and citizenship. On the one hand, there was increasing public alarm about LGBTQ youth in schools. Recently intensified media coverage on gay-bashing and subsequent gay youth suicides had culminated in queer activist Dan Savage's popular It Gets Better YouTube campaign. During this time, the public demanded that something official be done about the alarming number of LGBTQ youth suicides. In response to the crisis, Bill 13 was advanced in Ontario to ensure that all publicly-funded secondary schools support and host GSAs - provided the students wanted one-and that "[b]oards and principals will not be able to prevent students from using the name GSA or another name the students may choose for these groups"7 (Ontario Ministry of Education, 2012, p. 2).

Despite broad support from a number of individuals and organizations for Bill 13, there was concurrent resistance to some of the issues implicitly advanced within the bill, including the premise that providing explicit and legislative platforms supporting GSAs was tacit acceptance that young people can embody 'non-cisgender' and 'non-heterosexual' sexual and gender identities. Echoing earlier protests against GSAs (Herriot, 2011), groups opposing Bill 13 argued that GSAs were an arm of a powerful gay lobby that, through social engineering, was redefining student subjectivity so radically that it infringed on parental and religious rights (see Lees, 2012). Opposition to Bill 13 can be understood as an example of moral regulation, wherein adults targeted GSA members with moralizing discourses to inhibit the clubs they deemed intrinsically immoral (for more on moral regulation, see Hunt, 1999). Given how prescribing and regulating particular gender, sexual, and citizen identities have always been a central aim of Canadian schools, this instance of moral regulation can be seen as a continuation of earlier policies, such as $20^{\text {th }}$ century prohibitions of female students from wearing pants, or restricting female enrollment in industrial arts.

While parental and political movements advanced strategies to regulate GSAs, youth themselves were being discursively reconstituted in the media and the legislature as having legitimate LGBTQ identities that should be affirmed within schools. Opponents responded to this discursive shift in student subjectivity by resurfacing a set of discourses and actions that disenfranchise (LGBTQ) youths' collective voice. For example, Tim Hudak, the leader of the Official Opposition strenuously objected to the premise in the Bill that afforded students control of the naming of GSAs by remarking that his "position is that principals run the schools with the parents and the school boards, not students" (Howlett, 2012). Hudak's remarks highlight the extent to which the power to name (especially to name queer identities) is reserved for adults exclusively, and that affording youth this power would undermine adults' exclusive right to run schools. In a poignant example of intersectionality, Hudak's remarks blend with his attempts to morally regulate the sexual and gender identities of youth (that is, to regulate young people back into the realm of heterosexual, cisgender patriarchy) by delegitimizing the active citizenship of young people within their schools.

The ages of protesters at public rallies both for and against Bill 13 outside of the Ontario Legislature during the spring of 2012 is notable here. While there is little doubt that at least some youth opposed Bill 13-after all, protection from peer-based bullying is still a central tenet of many GSAs_young people, either

\footnotetext{
7 This clause was added because publicly-funded Catholic boards insisted on renaming GSAs, such as "Open Arms", to avoid "promoting homosexuality".
} 
as individuals or a collective, did not constitute a presence in coverage of protests against Bill 13. This is to say, reports of protests against Bill 13 indicate that these demonstrations were organized and attended exclusively by adults. Conversely, there were several reports of public rallies in support of Bill 13 being organized and attended by youth, usually either GSA members or youths who wanted to form a GSA at their schools (Houston, 2012; Korducki, 2012). That adults as well as youth attended these demonstrations suggests intergenerational partnerships that were absent from those opposing Bill 13, and by their presence, youth demonstrate a commitment to participating in institutionalized democracy, albeit from the sidelines at a political protest (rather than, say, as elected members of the legislative assembly who could vote on Bill 13). While there are likely multiple reasons that youth chose to participate in Bill 13 rallies (for example, to impress peers or teachers, to be on the news, as something fun to do on a Saturday), it is plausible that they also thought there was a decent chance their participation could influence the final vote. Indeed, some of the youth protesting an anti-gay educational bill in Alberta in 2009 reported significant optimism that their civic action would yield tangible results (Herriot, 2014). This foray into political spaces indicates how youth are rejecting and subverting the more compliant forms of educational citizenship that have been foundational to citizenship education in Canada (see Westheimer, 2008).

The youth faction of pro-Bill 13 protesters is similar to the participation in GSAs more broadly, wherein youth, in conjunction with adults, collectively contribute to educational policy-making and broader public conversations around gender, sexuality, and schooling. In belonging to a GSA, members are expecting adults to take them seriously as citizens, not despite being young or LGBTQ (or allied), but as simultaneously embodying these legitimate subjectivities. In short, by insisting on the right to self-identify as a collective, they are practicing active citizenship.

\section{GSAs: Counter-publics that can reconstitute youth subjectivities}

While it was individual students who voiced earlier instances of students transgressing youth subjectivity norms, GSAs embody a type of student-centered counter-public employing collective consciousness-raising and action. As alternatives to the assumed equality of the public sphere within public schools-that is, that students are presumed to be treated equally when they are in a public school_GSAs enact "parallel discursive arenas where members of subordinated social groups invent and circulate counter-discourses to formulate oppositional interpretations of their identities, interests, and needs" (Fraser, 1992, p. 122-123). Having a student body fractured into a public and counter-public (and likely several counter-publics) does a few things to adult conceptions of youth subjectivity. Beyond establishing heterogeneity among young people, the existence of a counter-public is indicative of students having political capabilities and the willingness to assert these competencies in schools. It is also demonstrative of how youth are self-identifying, often insistently so, in ways that run counter to how adults choose to, and often insist on, identifying them. The struggle over naming, and the right to action, constitutes a shift from historical and dominant understandings of youth, wherein their subjectivity is politically deficient and subordinated by more politically capable adults.

In this way, GSA members can be understood as examples of Smith's $(2011 ; 2014)$ archetype of the Athenian child. Analogous to Jenks' (2005) Dionysian and Apollonian children,

the Athenian child is associated with child-rearing norms in which welfare is closely associated with autonomy, so that the child is in a sense a 'partner' in the socialization process. Daughter of Zeus, Athena emerged from her father's forehead fully grown-she is thus the perfect representative of the (partially) self-governing 'competent child-actor'. (Smith, 2011, p. 31)

Unlike the Dionysian or Apollonian child, who must be separated from adults (in the Dionysian case, to protect adult society from corruptive children, whereas the Apollonian innocent merited protection from adults' corrupting influences), the Athenian child is afforded "voice" and "choice" while participating in a multi-generational world. GSAs can, therefore, be recognized as collectives of the Athenian child in schools, 
wherein youth have choices in naming their own, often diverse, sexual and gender identities, and also the voice to advocate for the affirmation of those identities. Embodying the Athenian child, itself a new theoretical concept, indicates how GSAs create space for a new archetype of the child, which in turn allows the possibility that this new archetype could eventually jostle for space amongst its Dionysian and Apollonian siblings, as a dominant schematic for understanding childhood.

\section{Conclusion}

GSAs are still a relatively new phenomenon. Their emergence, while facilitated by legislation such as Bill 13, is by no means secure, and youth continue to report significant barriers in establishing them at all. Furthermore, LGBTQ youth do not universally embrace GSAs, with some rejecting them outright (Haskell \& Burtch, 2010). With growing social and political inclusion and acceptance of LGBTQ youth in schools, GSAs could disappear altogether.

I would be surprised, however, if they did. GSAs provide one of the few, if not the only, opportunities for youth to make meaningful political change within their own educational experiences. While the student government's power is typically relegated to such minutia as choosing the theme of the school dance, GSAs engage with teachers, administrators, and even elected officials, to lobby and enact change that is less superficial than choosing between a Winter Wonderland or a Valentine's Sock Hop. This alone will likely be a tantalizing pull for youth to continue forming and joining GSAs. GSAs have also gained enough traction that they are now practically, financially, and technologically supported by a number of outside adult coalitionsEGALE's mygsa.ca in particular-which facilitates their emergence and maintenance. Bolstered by such support, GSAs will likely continue to exist at least within Canada.

The continuation of GSAs bodes well for researchers interested in childhood and youth cultures, as they are unique embodiments of the newly developed Athenian child archetype. The alchemy of LGBTQ and allied youth organizing politically within public education marks a departure not just from expectations of how youth should behave in schools, but also of youth subjectivity more broadly. In their diversity, GSAs have LGBTQ members as well as allies-all with varying levels of civic engagement-who create space to reimagine and redefine subjectivity not just for themselves, but for all youth. In so doing, they are a trend to be watched closely.

\section{Acknowledgements}

The author gratefully acknowledges the late Dr. Stephen Norris of the University of Alberta for the conversations that led to the ideas for this paper, and for his encouraging feedback during early drafts. The author also thanks Dr. Don Cochrane and Dr. Rod Knight for editorial support and revisions.

\section{References}

Adams, Carly. (2014). Supervised places to play: social reform, citizenship, and femininity at municipal playgrounds in London, Ontario, 1900-1942. Ontario Historical Society, 3(1), 61-81. Retrieved from https://www.uleth.ca/dspace/bitstream/handle/10133/3420/adams\%20OH\%20spring\%202011.pd f? sequence $=1$

Axelrod, P. (1997). The promise of schooling: Education in Canada, 1800-1914. Toronto, ON: University of Toronto Press.

Bruhm, S. \& Hurley, N. (2004). Curiouser: On the queerness of children. In S. Bruhm\& N. Hurley (Eds.), Curiouser: On the queerness of children (pp. ix-xxxvi). Minneapolis, MN: University of Minnesota Press.

CBC News (2012, February 29). Anti-bullying rally organizers say they were punished. CBC News. Retrieved from http://www.cbc.ca/news/canada/new-brunswick/anti-bullying-rally-organizers-say-they-werepunished-1.1193360 
Cairns, J. (2014, February 18). Rainbow flag raised at city hall. Battleford's News-Optimist. Retrieved from http://www.newsoptimist.ca/article/20140218/BATTLEFORD0101/302189983/-

$1 /$ battleford01/rainbow-flag-raised-at-city-hall

Cohen, E. F. (2009). Citizenship and semi-citizenship in democracies. Cambridge: Cambridge University Press.

Curtis, B. (1994). 'Illicit' sexuality and public education, 1840-1907. In S. Prentice (Ed.), Sex in schools:

Canadian education and sexual regulation. Montreal: Our Schools/Our Selves Education Foundation.

CTV Atlantic (2012). Anti-bullying protests continue at Leo Hayes High School. CTV News. Retrieved from http://atlantic.ctvnews.ca/anti-bullying-protests-continue-at-leo-hayes-high-school-1.774220

DiMascio, A. (2010). Educational discourse and the making of educational legislation in early Upper Canada. History of Education Quarterly, 50(1), 34-54.

EGALE Canada Human Rights Trust. (2011). Every class in every school: Final report on the first national climate survey on homophobia, biphobia, and transphobia in Canadian schools. Toronto, ON: EGALE Canada Human Rights Trust.

Egan, R. D., \& Hawkes, G. (2010). Theorizing the sexual cbild in modernity. New York, NY: Palgrave MacMillian.

Egan, R. D. (2013). Becoming sexual: A critical appraisal of the sexualisation of girls. Cambridge, MA: Polity Press.

Faulkner, J. (2011). The importance of being innocent: Why we worry about cbildren. Melbourne, AU: Cambridge University Press.

Fetner, T., \& Kush, K. (2008). Gay-straight alliances in high schools: Social predictors of early adoption. Youth \& Society, 40(1), 114-130. doi: 10.1177/0044118X07308073

Fetner, T., Elafros, A., Bortolin, S. \& Drechsler, C. (2012). Safe spaces: Gay Straight Alliances in high schools. Canadian Review of Sociology, 49(2), 188-207. doi: 10.1111/j.1755-618X.2011.01290.x

Fields, J. (2004). Same-sex marriage, sodomy laws, and the sexual lives of youth. Sexuality Research and Social Policy: Journal of the NSRC, 1(1), 11-23.

Fraser, N. (1992). Rethinking the public sphere: A contribution to the critique of actually existing democracy. In C. Calhoun (Ed.), Habermas and the public sphere (pp. 109-142). Cambridge, MA: MIT Press.

Gagen, E. A. (2000). Playing the part: Performing gender in America's playgrounds. In S. L. Holloway \& G. Valentine (Eds.), Children's geographies: Playing, living, learning (pp. 184-198). London: Routledge.

Gleason, M. (2001). Disciplining the student body: Schooling and the construction of Canadian children's bodies, 1930-1960. History of Education Quarterly, 41(2), 189-215.

Gray, M. L. (2009). Out in the country: Youth, media, and queer visibility in rural America. New York, NY: New York University Press.

Gulli, C. (2014, January 13). What happens when your son tells you he's really a girl?: Inside the families embracing the new world of gender variance. MacLean's Magazine. Retrieved from http://www.macleans.ca/society/health/what-happens-when-your-son-tells-you-hes-really-a-girl/

Haskell, R., \& Burtch, B. E. (2010). Get that freak: Homophobia and transphobia in high schools. Halifax, NS: Fernwood Pub.

Herriot, L. (2011). Trends in Canadian newspaper coverage of gay straight alliances: 2000-2009. Journal of LGBT Youth 8(3), 215-233. doi: 10.1080/19361653.2011.584205

Herriot, L. (2014). The presence of an absence: Youth participation in macro-level educational reform. Citizenship Teaching \& Learning, 9(1), 35-52. doi: 10.1386/ctl.9.1.35_1

Houston, A. (2012, March 29). Anti-bullying bills spark protests at Ontario legislature. Daily Xtra. Retrieved from http://dailyxtra.com/canada/news/anti-bullying-bills-spark-protests-at-ontario-legislature

Howlett, K. (2012, June 5). Anti-bullying bill passes, clearing way for gay-straight alliances in Ontario schools. The Globe and Mail. Retrieved from http://www.theglobeandmail.com/news/politics/anti-bullyingbill-passes-clearing-way-for-gay-straight-alliances-in-ontario-schools/article4231542/

Hunt, A. (1999). Governing morals: A social history of moral regulation. Cambridge, UK: Cambridge University Press.

Hurley, C. (2014, February 8). Solidarity shown to queer community amongst Olympic boycott. The Western Star. Retrieved from http://www.thewesternstar.com/News/Local/2014-02-08/article3607922/Solidarity-shown-toward-queer-community-amidst-Olympics-boycott/1

Jenks, C. (2005). Childhood (2nd ed.). London, UK: Routledge. 
Korducki, K. (2012, May 14). GSA rally brings out the kids. Toronto Star. Retrieved from http://torontoist.com/2012/05/gsa-rally-brings-out-the-kids/

Lees, P. (2012). Report on Bill 13 - Accepting Schools Act. Family Coalition Party. Retrieved from http://www.familycoalitionparty.com/09_Download_Files/01_Bill_13/Bill\%2013\%20Accepting\%2 0Schools $\% 20$ Act $\% 20-\% 20$ Notes $\% 20$ from $\% 20$ Second $\% 20$ Reading.pdf

Ontario Ministry of Education (2012). Creating safe and accepting schools: Information for parents about the accepting schools act. Retrieved from http://www.edu.gov.on.ca/eng/safeschools/SafeAccepSchools.pdf

Mayo, J. B. Jr. (2013). Critical pedagogy enacted in the gay straight alliance: New possibilities for a third space in teacher development. Educational Researcher, 42(June/July), 267-275. doi: 10.3102/0013189X13491977

Pascoe, C. J. (2007). Dude, you're a fag: Masculinity and sexuality in high school. Berkeley, CA: University of California Press.

Peck, C. L., Sears, A., \& Herriot, L. (2012). Voiceless: Canadian high school students' conceptions of schools as democratic communities. Paper presented at Children's Identity \& Citizenship: European Association [Conference]. York, UK.

Rudduck, J. (2007). Student voice, student engagement, and school reform. In D. Thiessen and A. CookSather (Eds.), International Handbook of Student Experience in Elementary and Secondary School (pp. 587610). Dordrecht: Springer.

Robinson, K. H. (2013). Innocence, knowledge, and the construction of childhood: The contradictory nature of sexuality and censorship in children's contemporary lives. London, UK: Routledge.

Rose, N. (1999). Governing the soul (2nd ed.). London, UK: Routledge.

Russell, S. T., Muraco, A., Subramaniam, A., \& Laub, C. (2009). Youth empowerment and high school gay straight alliances. Journal of Youth and Adolescence, 38(7), 891-903.

Schilt, K. \& Westbrook, L. (2009). "Doing gender, doing heteronormativity: 'Gender normals,' transgender people, and the social maintenance of heterosexuality". Gender \& Society, 23(4), 440-464. doi:10.1177/0891243209340034.

Short, D. (2013). "Don't be so gay!": Queers, bullying, and making schools safe. Vancouver, BC: UBC Press.

Smith, K. M. (2011). Producing governable subjects: Images of childhood old and new. Childhood, 19(1), 2437. doi: $10.1177 / 0907568211401434$

Smith, K. M. (2014). The government of childhood: Discourse, power and subjectivity.

Stockton, K. B. (2009). The queer child, or growing sideways in the twentieth century. Durham, NC: Duke University Press.

Sutherland, N., Barman, J., \& Hale, L. L. (1992). History of Canadian childhood and youtb: A bibliography. Westport, Conn: Greenwood Press.

Urback, R. (2010, December 17). Don't drop the voting age. MacLean's Magazine. Retrieved fromhttp://oncampus.macleans.ca/education/2010/12/17/dont-drop-the-voting-age/

Vancouver School Board. (2014). Policy ACB: Sexual orientation and gender identities. Retrieved from http://www.vsb.bc.ca/district-policy/acb-sexual-orientation-and-gender-identities

Walton, G. (2004). Bullying and homophobia in Canadian schools: The politics of policies, programs, and educational leadership. Journal of LGBT Youth, 1(4), 23-36. doi: 10.1300/J367v01n04_03

Westheimer, J. (2008). What kind of citizen? Democratic dialogues in education. Education Canada Toronto, $48(3), 6-11$.

\section{About the Author}

Lindsay Herriot is a PhD student in the department of Educational Policy Studies at the University of Alberta. Lindsay's research interests include the roles of extra-curricular organizations in schools, LGBTQ* youth, childhood and adolescent theory, citizenship education, and student voice. Lindsay can be reached at lherriot@ualberta.ca. 